\title{
Students' Perception toward the Implementation of Synchronous Learning during COVID-19 Pandemic in English Language Teaching
} (ELT)

\author{
Tira Nur Fitria \\ Institut Teknologi Bisnis AAS Indonesia, Surakarta, Central Java \\ (tiranurfitria@gmail.com)
}

Article History: Submitted February $18^{\text {th }}, 2021$; Accepted April $4^{\text {th }}, 2021$; Published 1 June 2021

\begin{abstract}
During COVID-19 pandemic, educators implement online learning in the education process. Basic interactive models of online learning available, such as synchronous learning, as a face-to-face learning process through online media. This research investigates the students' perception toward the implementation of synchronous learning in ELT especially TOEFL. This research is qualitative. The results show that: 1) $51 \%$ of students use Zoom and Live YouTube in learning TOEFL. 2) $89.7 \%$ of students use mobile phones in online learning. 3) $49.7 \%$ of students agree that Zoom has complete features. 4) $83.2 \%$ of students agree that operating Zoom's features is very easy. 5) $74.2 \%$ of students agree that Zoom is easy-used. 6) $72.9 \%$ of students agree that using Zoom in learning TOEFL is effective. 7) $73 \%$ of students agree that using Live YouTube in learning TOEFL also effective. 8) $63.9 \%$ agree that in Zoom, they can participate by face-to-face interactions (e.g. question-answer even discussion with lecturer and classmates. 9) $95.5 \%$ of students agree that using YouTube, videos can be seen anytime and anywhere because videos are stored on the lecturer's channel. In the understanding level of TOEFL, $83.2 \%$ of students really understand in the listening section, $89.7 \%$ of students understand the reading section, and $81.3 \%$ of students understand the Structure and Written Expression section. Several problems affect learning TOEFL with Zoom and YouTube. Students have a problem with an internet connection. The other problems are internet quota, technical problems of the device (e.g battery, device dead suddenly, audio quality, device's video/audio, and others), device's type used, and surrounding conditions (e.g light conditions, sounds, or other disturbances). In the next learning system, $80.6 \%$ of students agree that the next learning system implements face-to-face learning and still uses Zoom and YouTube Live Streaming.
\end{abstract}

Keywords: ELT, synchronous learning, TOEFL, YouTube, Zoom

\begin{abstract}
Abstrak. Selama pandemi COVID-19, para pendidik menerapkan pembelajaran online dalam proses pendidikan. Model pembelajaran online interaktif dasar yang tersedia, seperti pembelajaran sinkron, sebagai proses pembelajaran tatap muka melalui media online. Penelitian ini mengkaji persepsi siswa terhadap penerapan pembelajaran sinkron di ELT khususnya TOEFL. Penelitian ini bersifat kualitatif. Hasil penelitian menunjukkan bahwa: 1) $51 \%$ siswa menggunakan Zoom dan Live YouTube dalam pembelajaran TOEFL. 2) 89,7\% siswa menggunakan ponsel dalam pembelajaran online. 3) 49,7\% siswa setuju bahwa Zoom memiliki fitur yang lengkap. 4) 83,2\% siswa setuju bahwa mengoperasikan fitur Zoom sangat mudah. 5) 74,2\% siswa setuju bahwa Zoom mudah digunakan. 6) 72,9\% siswa setuju bahwa menggunakan Zoom in learning TOEFL efektif. 7) 73\% siswa setuju bahwa menggunakan Live YouTube dalam pembelajaran TOEFL juga efektif. 8) 63,9\% setuju bahwa dengan Zoom, mereka dapat berpartisipasi dengan interaksi tatap muka (misalnya tanya jawab bahkan diskusi dengan dosen dan teman sekelas. 9) 95,5\% mahasiswa setuju bahwa dengan menggunakan YouTube, video dapat dilihat kapan saja dan di mana saja karena video disimpan di saluran dosen. Pada tingkat pemahaman TOEFL, 83,2\% siswa sangat memahami bagian menyimak, 89,7\% siswa memahami bagian membaca, dan 81,3\% siswa memahami
\end{abstract}


bagian Struktur dan Ekspresi Tertulis. Beberapa masalah memengaruhi pembelajaran TOEFL dengan Zoom dan YouTube. Siswa memiliki masalah dengan koneksi internet. Masalah lainnya adalah kuota internet, masalah teknis perangkat (misal baterai, perangkat mati mendadak, kualitas audio, video/audio perangkat, dan lain-lain), jenis perangkat yang digunakan, dan kondisi sekitarnya (misal kondisi cahaya, suara, atau gangguan lainnya). Pada sistem pembelajaran selanjutnya, 80,6\% siswa setuju bahwa sistem pembelajaran selanjutnya menerapkan pembelajaran tatap muka dan masih menggunakan Zoom dan YouTube Live Streaming.

Kata kunci: ELT, pembelajaran sinkronus, TOEFL, YouTube, Zoom

\section{INTRODUCTION}

The world is going through a critical, uncertain, and unpredictable stage of disaster and destruction because of COVID-19 pandemic (Sarkar, 2020). All the aspects of life are getting severely influenced including education. The recent COVID-19 pandemic has changed the way of education of millions of students (Fulsawange et al., 2020). The education system is going through a paradigm shift. Radical changes are being seen in the field of education in the form of digital technology. In classroom settings with desks, tables, and blackboards, teaching does not have to be done; it can be done in people's rooms, millions of miles away behind their personal computers (Lotfi \& Pozveh, 2019). All of a sudden new forms of learning like virtual learning, online learning, or digital learning replaced the traditional forms of face-to-face learning because of unavoidable circumstances during COVID-19 pandemic.

Tekerek (2020:29) states that the constraints of education "lockdown" due to COVID-19 pandemic increased the necessity to learn online. In mitigating the spread of this pandemic policymakers as much as possible, these online initiatives have changed the face of the school/institution traditional education system to a great extent. Several challenges as well are being faced by the teachers and students. Since the options are limited during COVID19 pandemic, teachers and students are asked to go through online activities to continue the education process as much as possible. Rising to the occasion, many digital platforms are being increasingly made available by the government to provide students free access to the learning materials. The virtual platforms of learning or e-learning platform have given hope to the teachers and students during this pandemic.

According to Fulsawange et al. (2020:51), online learning or e-learning is implemented during the teaching and learning process remotely on digital platforms. E-learning uses network technology, or it can be said online system facilitates learning (Fitria, 2021). The pandemic offers higher education institutions outstanding training to test their readiness for and implementation of online learning (Daniel, 2021:36). The emergence of Information and Communication Technology (ICT) innovations in learning has enabled learning to take place anywhere and wherever (Shukri et al., 2020). Stimulus and increased learner engagement within the classroom have been applied by infusing innovations in classroom instruction. Guzacheva (2020) states that in almost every sector, distance learning has a vast presence. Language teaching is one such area where the methods of learning have been taken over and changed by technology. 
There are two basic interactive models of online education or online learning (e-learning), they are asynchronous and synchronous (Gulsun, 2015:111). Asynchronous means that the learners and the facilitator do not participate in the meeting at the same time, for example, emails, web, blog, internet chat, and many more. The nature of participating asynchronously is key in online courses. This encourages participants to be able to balance time for college with families, jobs, and other duties. Under comfortable conditions, learners can conveniently log into the e-learning site from any virtual location and then download or exchange documents and give their peers and/or teachers emails. Students also can spend time polishing their assignments and contributions. Hong $\mathrm{Ng}$ (2020) states that the biggest challenge is how to use synchronous learning to promote those connections without permitting face-to-face sessions due to the need to expand physical distance.

Hofmann (2003:10) states that "synchronous" refers to training delivered in real-time by a facilitator, such as synchronous communications usually over the internet, including phone calls, text messages, video conferences, whiteboard meetings, and synchronous classes. Synchronous learning is characterized by group contact between participants and cooperation between them. Synchronous means that the learners, or learners, and the facilitator participate in the conference at the same time, for example, video conferencing. It is also supported by (Chaska, 2000) that the use of desktop video conferencing over the internet is providing synchronous learning among widely dispersed sites. Perveen (2016) states that synchronous e-learning applies to learning/teaching concurrently using an electronic mode. For teachers and students, the synchronous interactive classroom is a space to connect and communicate in real-time. It parallels the conventional classroom by way of webcams and class discussion features, except that all members access it directly over the Internet.

Synchronous teaching and learning or real-time teaching-learning is multifaced and can be conceptualized as both short-form or long-form, depending on the purpose and platform of the learning (Jiyoon \& Peggy, 2019). In longer form, the example as web videoconferencing or web-conferencing programs where multimedia such as audio and video are used in addition to interactive tools such as chat and whiteboard. According to Caporali \& Trajkovik (2012:89), synchronous learning is learning in which the parties participate at the same time. Richard (2008:108) also states that video conferences are described as synchronous.

Video conferencing includes two-way video, voice, and data communication over a remote link between two or more parties (Caporali \& Trajkovik, 2012:3). It is carried out over a variety of media. Streaming technology such as also makes the use of video conferencing facilities covering the one-way transfer of audio and video to a future end-user of other content. Holsapple (2003:123) states that video conferencing encourages information to be shared by people and communities. The speaker is known as the host, while the one being called is the visitor or user, and it is close to the telephone. A video conference may be arranged for a future period by the caller or host. In general, the guest or participant will be told by e-mail of the meeting time, then they will engage in the video conference at that time.

According to Krakower \& Blumengarten (2020), many benefits of video conferencing include improving relationships and the flexibility of learning collaboration by using interactive whiteboards, laptops, tablets, computers, or smartphones to conduct conferences. But, sometimes during video conferences, experience a bad connection or unstable connection, the video might freeze, a delay or lag can happen, unstable audio, blurry images, or the inability to share screen. There are some examples of video conferencing tools based on the expert. (Simonson et al., 2018:14) state that there are several options to create 
orientations is to have a synchronous meeting/class by using video conferencing platforms such as Zoom (https://zoom.us/), Facebook Live https://live.fb.com/, GoToTraining (https://www.gotomeeting.com/training) or Google Hangout (https://hangouts.google. com/). Emtinan (2019:191) states that synchronous tools such as Youtube Live, Facebook Live, Zoom, and many more. Atti (2019:17-18) explains that some online meetings and video conferencing such as Zoom, Hangout, Online Broadcasting Software (OBS), Youtube, Skype, and many more. While, Waghmare \& Waghmare (2020:97) define that the most used online video conferencing tools for online teaching nowadays is Google Hangout, Google Meet, Google Classroom, Team, Webex, and Zoom.

There are several studies conducted related to synchronous learning (e-learning). The first research was written by Shukri et al. (2020). This study explores the experience of students using ICT resources to learn English using Zoom Cloud Conference, Microsoft Teams, and VLE as the synchronous learning medium. The second research was written by Fitria (2020). This study examines the online learning method in teaching English and the opinion of the lecturers on the use of the online learning system. The third research was written by Ghazal et al. (2015). This study determines how postgraduate students use Skype-based video conferencing for synchronous distance education classes. The fourth research was written by Dewi et al. (2019). This study examines the perception of students on the design of asynchronous online discussion using Schoology. The fifth research was written by Rahayu, (2020). This study explores the students' experience use synchronous e-learning through the Zoom conference system.

Based on the previous studies above, there are several similarities and differences with this research. In similarity, all studies discuss synchronous learning. The first study discusses synchronous learning by using Zoom Cloud Conference, Microsoft Teams, and VLE. The second study discusses asynchronous and synchronous learning. The third study only discusses synchronous learning by using Skype. The fourth study discusses synchronous learning using Schoology. While in the fifth study discusses synchronous learning using Zoom.

Based on the previous studies above, the researcher is interested in discussing synchronous learning. The researcher limits the object of study by using Zoom meetings and YouTube Live Streaming because the researcher uses both those media for English language learning. Therefore, the purposes of this research are to know the implementation of synchronous learning both Zoom meeting and YouTube Live Streaming and to know the students' perception toward the implementation of synchronous learning in English Language teaching (ELT) especially English TOEFL.

\section{METHOD}

This research is descriptive qualitative. According to Horvat (2015:8), qualitative research is particularly well suited to describe and understand the process or problems. The purpose of this descriptive study is to make descriptions, descriptions, or paintings systematically, factually, and accurately. This study does not require statistical testing; is temporary and subject to change during data collection and analysis.

In collecting data, the researcher used a questionnaire. The type of questionnaire used is an online questionnaire. The type of questionnaire used is the closed-ended question. The respondents were asked to complete the questionnaire electronically and the result could be 
seen then analyzed by the researcher (Gratton \& Jones, 2010). The respondents of this research were the 155 students of the fifth semester in ITB AAS Indonesia, Surakarta. They were asked to fill the online questionnaire which consists of several questions related to the evaluation of synchronous learning by using Zoom which was streamed on YouTube Live Streaming during the English teaching and learning process in the academic year 2020/2021.

In analyzing data, the researcher used three steps of analysis such as data reduction, data display, and conclusion (Punch, 2013:172). In data reduction, the researcher reduced data to select and summarize the incoming data. In presenting data, the researcher synthesized complex information into a systematic form, so that it became simpler and provided the possibility of drawing data conclusions with brief descriptions, charts, tables, or graphs. Then, the researcher made conclusions based on what has been previously analyzed.

\section{RESULTS AND DISCUSSION}

\section{Results}

This research is to know the implementation of synchronous learning in both Zoom meetings and YouTube Live Streaming and to know the students' perception toward the implementation of synchronous learning in English Language teaching (ELT). The findings show:

1. The types of platform that are often used in the English TOEFL learning process for one semester
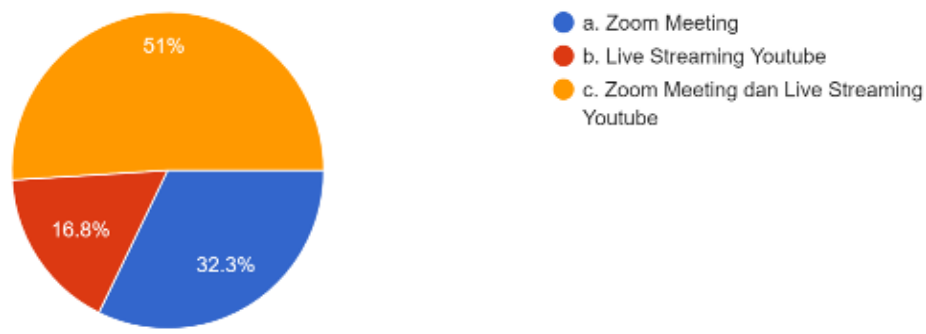

Figure 1 The Types of Platform Often Used in the English TOEFL Course

Figure 1 shows that there are two types of platforms used by the teacher in teaching TOEFL, namely Zoom meetings and YouTube Live Streaming. There are155 students learning English TOEFL as respondents in this research. There are 79 students or $51 \%$ use platforms both Zoom meeting and YouTube Live Streaming. There are 50 students or $32.3 \%$ use the platform Zoom meeting, and 26 students, or $16.8 \%$ use YouTube Live Streaming. It shows that most students use platforms both Zoom meetings and YouTube Live Streaming in the teaching and learning process of English TOEFL. 
2. The types of device often used in the English TOEFL learning process with Zoom Meeting and Live Streaming on YouTube
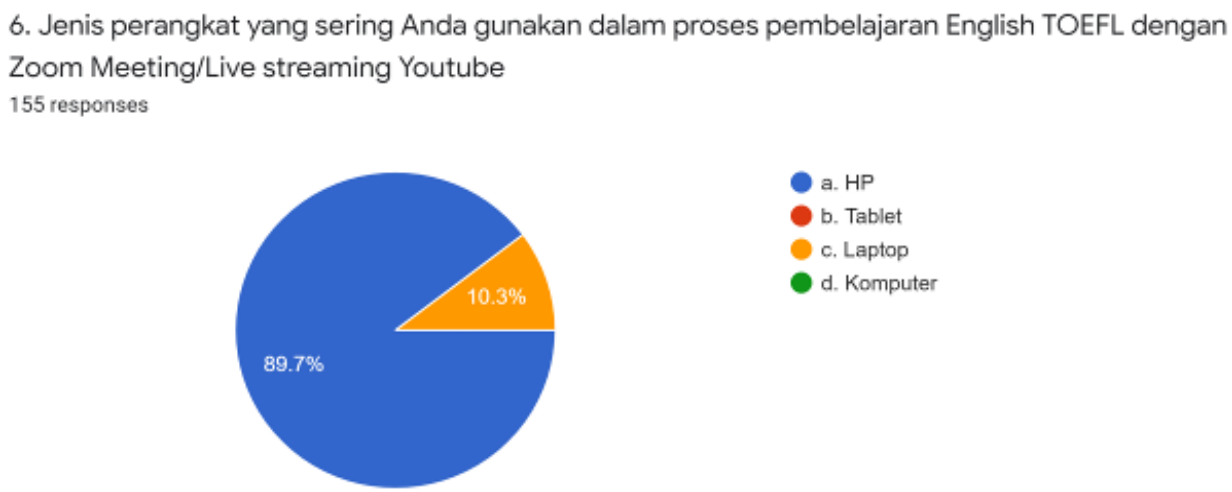

Figure 2 The Types of Device Used by Students in Learning English TOEFL

Figure 2 shows that there are only two devices where the students often use in learning English TOEFL with Zoom Meeting and Live streaming on YouTube, namely are mobile phone and laptop. As many as 139 students $(89.7 \%)$ use a mobile phone, while only 16 students or $7.3 \%$ use a laptop. There are no students who use tablets and computers in learning English TOEFL. It shows that most students often use mobile phones in learning English TOEFL during the teaching and learning process.

3. The completeness of the features in the Zoom Application in the learning process

8. Menurut anda, seberapa lengkap fitur-fitur yang ada di dalam Aplikasi Zoom dalam proses pembelajaran

155 responses

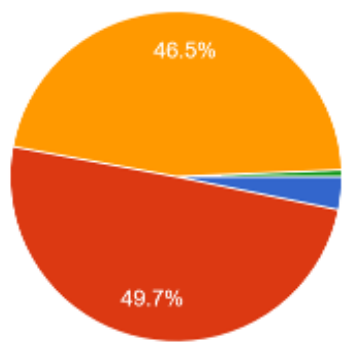

$$
\begin{aligned}
& \text { a. Sangat lengkap } \\
& \text { b. Lengkap } \\
& \text { c. Cukup lengkap } \\
& \text { d. Tidak lengkap }
\end{aligned}
$$

Figure 3 The Completeness of the Features in Zoom Meeting Application

Figure 3 shows that 77 (49. $7 \%$ ) state "complete", 72 students or $46.5 \%$ state "complete enough", 5 students or $3.2 \%$ state "very complete", while only 1 student or $0.6 \%$ state "not complete". It shows that most students agree that the features in the Zoom Meeting Application have complete features. 
4. The level of ease of use of the features in the Zoom application in the learning process during 1 semester

9. Menurut anda, seberapa mudah penggunaan fitur-fitur yang ada di aplikasi Zoom dalam proses pembelajaran selama 1 semester 155 responses
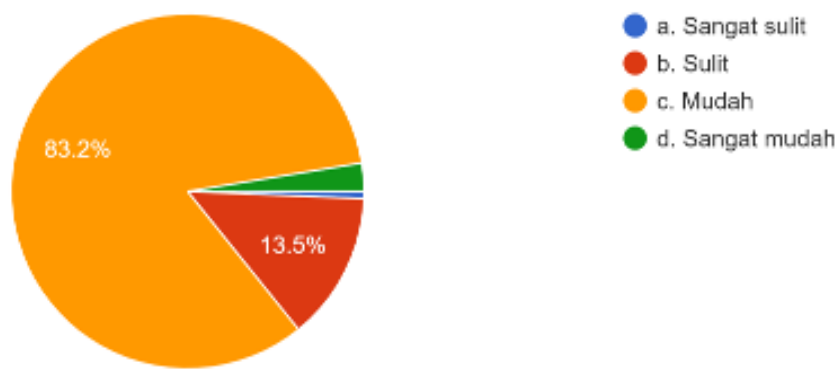

Figure 4 The Level of Ease of Use of the Features in Zoom Application

Figure 4 shows that 129 students or $83.2 \%$ states "easy". Twenty-one (21) students or 13.5 $\%$ state "difficult", 4 students or $2.6 \%$ state "very easy", while only 1 student or $0.6 \%$ state "very difficult". It shows that most students agree that very easy in using the Zoom Meeting features in learning English TOEFL.

5. The level of ease of using the Zoom Meeting application in the learning process

\section{Menurut anda, seberapa mudah penggunaan aplikasi Zoom dalam proses pembelajaran} 155 responses

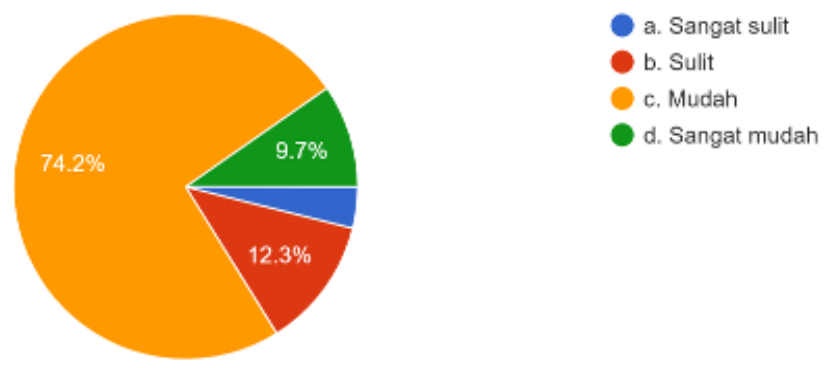

Figure 5 The Level of Ease of Using Zoom Meeting Application

Based on Figure 5 above, there are 115 students or $74.2 \%$ state "very difficult". Nineteen (19) students or $12.3 \%$ state "difficult", 15 students or $9.7 \%$ state "very easy", while only 6 students or $3.9 \%$ state "very difficult". It shows that most students agree that the Zoom Meeting application is very easy to use in learning English TOEFL. 
6. The level of effectiveness of using Zoom meetings in learning English TOEFL for 1 semester

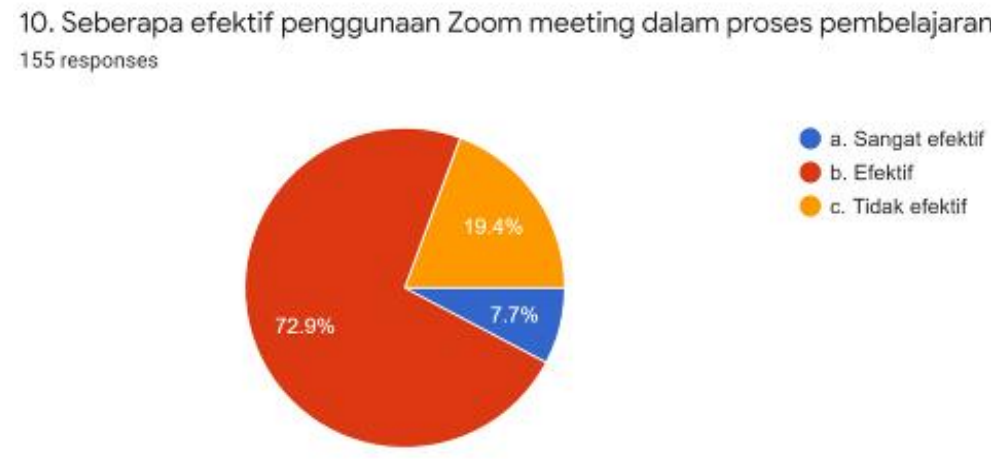

Figure 6 The Level of Effectiveness of Using Zoom Meetings in Learning English TOEFL

Based on Figure 6 above, there are three levels of effectiveness of using Zoom. As many as 113 students or $72.9 \%$ state "effective", 12 students or $2.7 \%$ state "very effective", while 30 students or $19.4 \%$ state "not effective". It shows that most students agree that the use of the Zoom Meeting application in learning English TOEFL is effective during one semester.

7. The level of effectiveness of YouTube Live Streaming in the learning English TOEFL during 1 semester
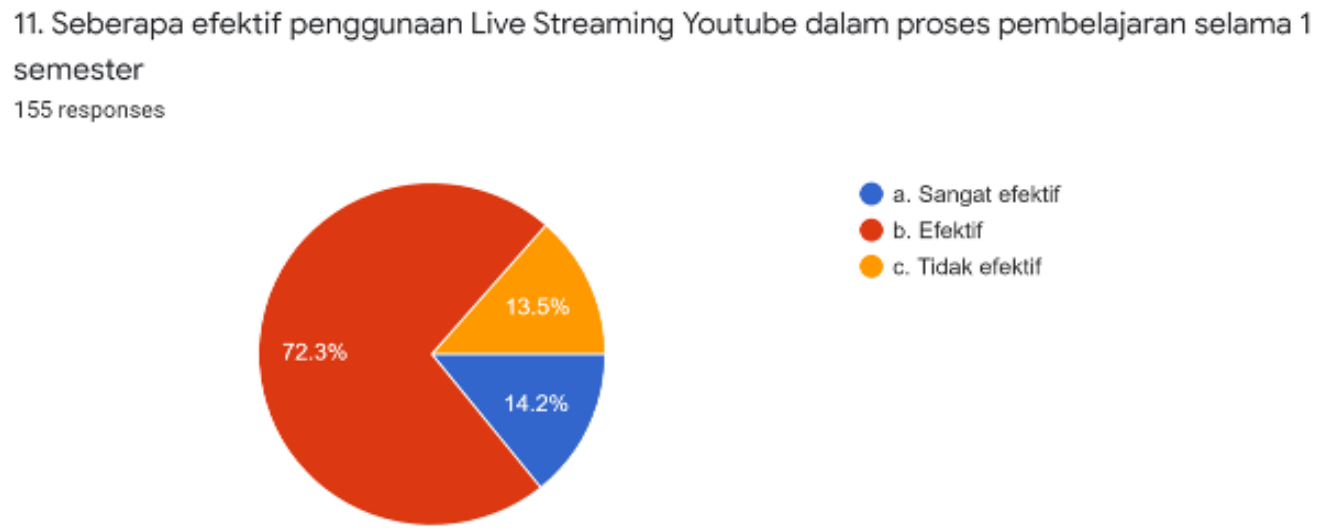

a. Sangat efektif

b. Efektif

c. Tidak efektif

Figure 7 The Level of Effectiveness of YouTube Live Streaming in Learning TOEFL

Based on Figure 7 above, there are three levels of effectiveness of using YouTube Live Streaming. There are 112 students or $73 \%$ who state "effective", 22 students or $14.2 \%$ who state "very effective", while 21 students or $13.5 \%$ state "not effective". It shows that most students agree that the use of YouTube Live Streaming in learning English TOEFL is effective during 1 semester. 
8. The advantages of using Zoom meetings in the English TOEFL learning process

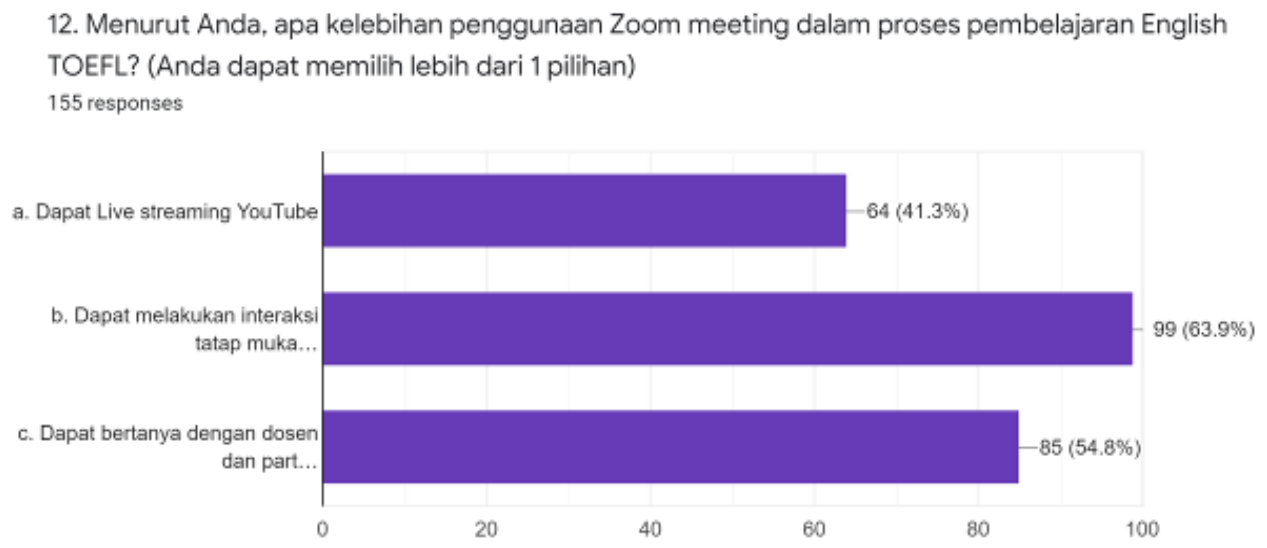

Figure 8 The Advantages of Using Zoom Meetings in Learning English TOEFL

Based on Figure 8 above, there are some advantages of using the Zoom Meeting application in learning English TOEFL. There are 64 students or $41.3 \%$ who state that "Zoom meetings can be linked with a YouTube live stream". Ninety-nine (99) students or $63.9 \%$ state that "With Zoom Meeting, students can make face-to-face interactions such as question-answer even discussion with English lecturers and other classmates". Eighty five (85) students or $54.8 \%$ state that "With Zoom Meeting, students can ask questions with English lecturers and other participants through the chat column in the Zoom meeting for "everyone" and "privately". It shows that most students agree that the students can make face-to-face interactions such as question-answer even discussion with English lecturers and other classmates/participants by using Zoom Meeting,

9. The advantages of using YouTube Live Streaming in the English TOEFL learning process

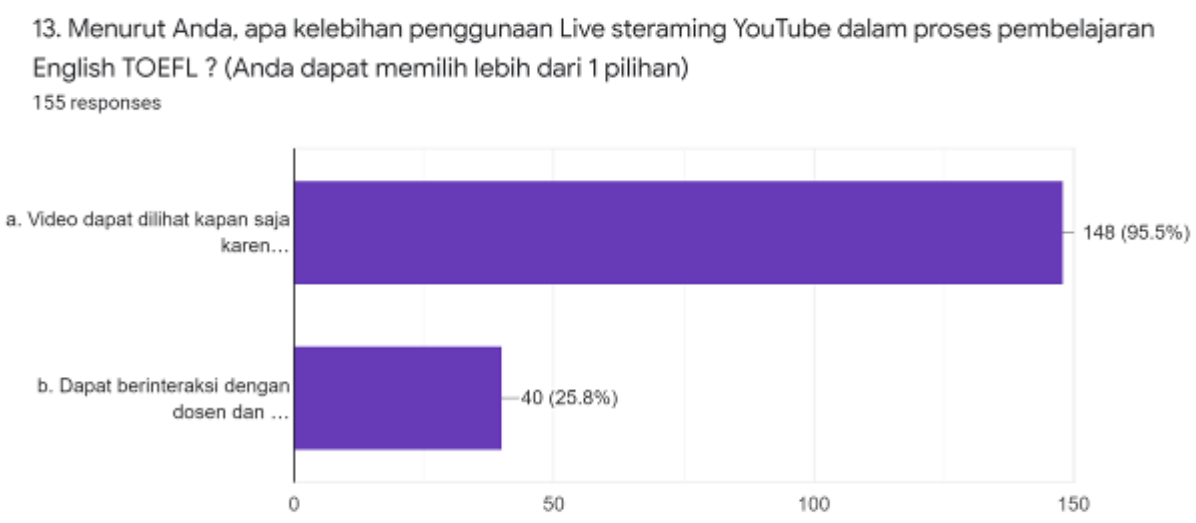

Figure 9 The Advantages of Using YouTube Live Streaming in Learning English TOEFL

Figure 9 above shows that there are some advantages of using YouTube Live Streaming in learning English TOEFL. There are 148 students or 95.5\% who state "With YouTube Live Streaming, TOEFL learning videos can be seen anytime and anywhere". While, 40 students, or $25.8 \%$ state "With YouTube Live Streaming, students can interact with questions and answer with the lecturers via Live Chat available during streaming. It shows that most 
students agree that in learning English TOEFL by using YouTube Live Streaming. Videos can be seen anytime and anywhere because the videos are automatically stored on the English lecturer's channel.

10. The level of understanding of the TOEFL material delivered by the lecturer using Zoom Meeting and YouTube Live Streaming

Table 1 The Level of Understanding of English TOEFL material Using lecturer using Zoom Meeting and YouTube Live Streaming

\begin{tabular}{llll}
\hline \multicolumn{1}{c}{ TOEFL Section } & \multicolumn{3}{c}{ Indicator } \\
\cline { 2 - 4 } & \multicolumn{1}{c}{$\begin{array}{c}\text { Really } \\
\text { Understand }\end{array}$} & Understand & Not Understand \\
\hline Listening & $129(83.2 \%)$ & $9(5.8 \%)$ & $17(11 \%)$ \\
\hline Reading & $10(6.5 \%)$ & $139(89.7 \%)$ & $6(3.9 \%)$ \\
\hline Structure and Written Expression & $8(5.2 \%)$ & $126(81.3 \%)$ & $21(13.5 \%)$ \\
\hline
\end{tabular}

Based on Table 1 above, there are three sections of TOEFL material. In the listening section, 129 students or 83.2 states 'very understand', 9 students or $5.8 \%$ state 'understand', and 17 students or $11 \%$ state 'not understand'. It shows that most students very understand TOEFL material especially the listening section. In the reading section, only 10 students or $6.5 \%$ state 'really understand', 139 students or $89.7 \%$ state 'understand', and only 6 students or $3.9 \%$ state "not understand". It shows that most students understand TOEFL material especially the reading section. In the Structure and Written Expression section, only 8 students, or $5.2 \%$ state "really understand", 126 students or $81.3 \%$ state "understand", and 21 students state "not understand". It shows that most students understand TOEFL material especially the Structure and Written Expression section.

11. The Students' problems that affect the English TOEFL learning process with Zoom Meeting and YouTube Live Streaming

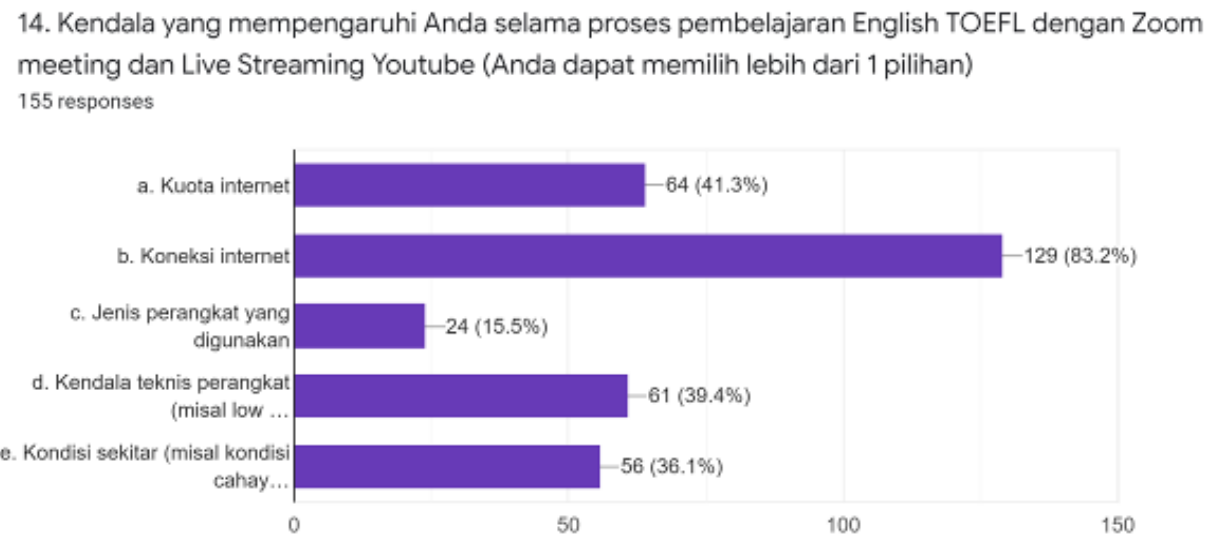

Figure 10 Problems that Affect in Learning English TOEFL with Zoom Meeting and YouTube Live Streaming

Figure 10 above shows that there are some problems faced by students in using Zoom Meeting and YouTube Live Streaming in learning English TOEFL. There are 64 students or $41.3 \%$ who state "internet quota", 129 students or $83.2 \%$ state "internet connection", 24 students or $15.5 \%$ state "type of device used", 61 students or $39.4 \%$ state "technical 
problems of the device (such as a low battery, the dead device suddenly, audio quality, video on the device and others), and 56 students or $36.1 \%$ state "surrounding conditions (such as light conditions, ambient sounds, or other disturbances)". It shows that most students have a problem with internet connection in using Zoom Meeting and YouTube Live Streaming in learning English TOEFL.

12. Continuity of using the next learning system in learning TOEFL Prediction 2

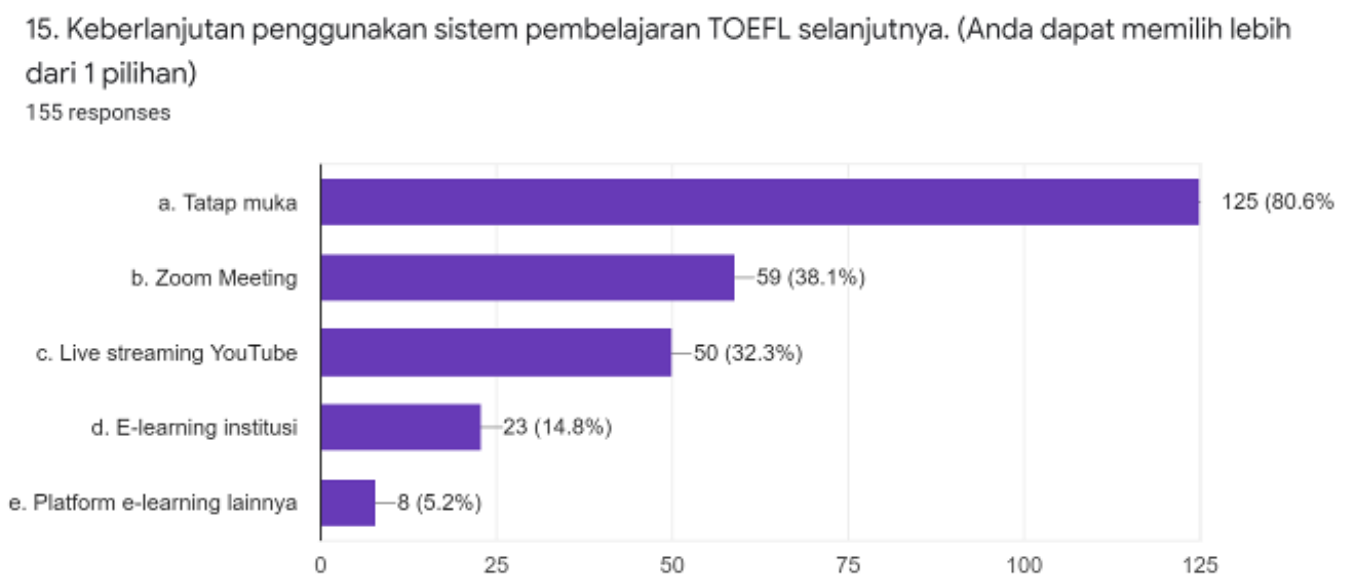

Figure 11 Continuity of Using the Next Learning System in learning TOEFL Prediction 2

Figure 11 shows that there are several choices of the students in using the next learning system. As many as 125 students or $80.6 \%$ state "face-to-face learning", 59 students or 38.1 $\%$ state "Zoom Meeting", 50 students or $32.3 \%$ state "YouTube Live Streaming", and 23 students or $14.8 \%$ state "institutions' e-learning platform". Only 8 students or $5.2 \%$ state "other e-learning platform". It shows that most students agree that the next learning system on English TOEFL prediction 2 implements face-to-face teaching and learning process.

\section{Discussion}

There are two types of platforms used by the teacher in teaching English TOEFL course by using Zoom meeting and YouTube Live Streaming during one semester in the academic year 2020/2021. There are 155 students in the fifth semester in ITB AAS Indonesia as a research object. In classroom settings with desks, tables, and blackboards, teaching does not have to be done; it can be done in people's rooms, millions of miles away behind their personal computers. This led to the asynchronous system of teaching, in which teaching and learning have a period. While this has now been synchronous with the use of interactive applications with which we can use live links, this is much like teaching in the classroom (Bernard et al., 2004).

During the COVID-19 pandemic, a Zoom video conferencing application is currently one of the tools most often used by lecturers for two-way or synchronous communication media in the teaching and learning process. According to Simonson et al., (2018, pp. 44-45), Zoom is a simple online video conferencing tool that can be used to meet with classes. Lecturers/teachers and students enjoy seeing each other through the application's video conferencing capabilities. The use of Zoom as a synchronous classroom meeting place facilitates lecturers/teachers and students' engagement. The meeting room encourages students to collaborate through Zoom's grouping. A zoom is a tool used to video conference 
allowing the option to teach, discuss, share computer screen, use interactive, whiteboards, break into smaller groups in separate rooms for small group activities and discussion and recording (Mary, 2019:62). The students can attend from any geographical location with an internet connection and video capability.

In participating in Zoom video conferences, the users can participate via phones, tablets, and computers of a supported type. According to Manning \& Johnson (2020:247), Zoom provides interactive features that allow users to share voice, text, presentations, whiteboards, each other's computer screens, and many more. Most students (139 students or $89.7 \%$ ) used mobile phones in learning English TOEFL during the teaching and learning process.

In general, the Zoom application has a feature that allows its users to stream Zoom Meeting or YouTube. This is indeed present to provide the possibility for students who are not connected to the meeting room to still be able to attend the meeting directly through the YouTube channel. However, this streaming process will also delay for a few seconds (around 20 seconds) between the actual Zoom Meeting and YouTube Live. Besides, those who watch meetings/webinars from YouTube can only provide comments via the live chat column provided on YouTube, and cannot interact directly with meeting participants who enter the Meeting Room on the Zoom application. Most students (79 students or $50.1 \%$ ) used the platform both Zoom meeting and YouTube Live Streaming in learning English TOEFL course during one semester.

The features of Zoom encourage English teachers, through rich experiences with students, to explore and evaluate the abilities. Zoom motivates English teachers to annotate their shared computer, making lessons more engaging, in addition to screen sharing. If the teacher allows this function, English teachers can record their lessons to the Cloud, or locallymedical students can also record and turn recording on and off as many times as they like during a lesson. Teachers can record lessons and review them again to determine the successes and deficiencies of students, and learners can self-evaluate their abilities by reviewing recorded lessons. To see the improvement over time, medical learners can watch the recorded lessons in a sequence. Besides, lecturers will evaluate the progress of the students by showing another English teacher, whom they trust, the reported lesson, and asking for positive input. From the findings, most students (77 students or $49.7 \%$ ) agreed that the features in the Zoom Meeting Application have complete features. Most students (129 students or $83.2 \%$ ) also agreed that using the Zoom Meeting features in learning English TOEFL was very easy for them. Most students (115 students or 74.2\%) agreed that very easy in using the Zoom Meeting application in learning English TOEFL.

Zoom allows English teachers to present the material of their lessons in different ways. The screen sharing of Zoom will provide English teachers with a fantastic opportunity to improve the intercultural skills of medical students by sharing interactive resources such as photographs, papers, and presentations. English teachers should enable medical learners to use constructive questions during lessons and after seeing them assess and evaluate their learning. Educators may even ask students, by taking a video and posting it, to focus on their classes. Most students (113 students or $72.9 \%$ ) agreed that the use of the Zoom Meeting application in learning English TOEFL was effective during one semester. Zoom is a platform for online conferencing, helping teachers/educators to have interactive meetings. It is a renowned framework that is used in a simulated set up to simulate the class environment. It has various characteristics that allow it to do so, such as video conferencing, audio conferencing, screen sharing, live chats, meeting video recording, and much more. Before 
developing their course, ESL teachers planning on using this framework should become acquainted with it.

There are some advantages of using the Zoom Meeting application in learning English TOEFL. It showed that most students (99 students or $63.9 \%$ ) agreed that the students can make face-to-face interactions such as question-answer even discussion with English lecturers and other classmates/participants by using Zoom Meeting. 64 students agreed that Zoom meetings can be linked with a YouTube live stream". While 85 students or $54.8 \%$ agreed that Zoom Meeting, students can ask questions with English lecturers and other participants through the chat column in the Zoom meeting for "everyone" and "privately".

Besides using Zoom Meeting, most students (112 students or $73 \%$ ) agreed that the use of YouTube Live Streaming in learning English TOEFL also effective to be implemented during 1 semester. There are some advantages of using YouTube Live Streaming in learning English TOEFL. Most students (148 students or 95.5\%) agreed that in learning English TOEFL by using YouTube Live Streaming, videos can be seen anytime and anywhere because the videos are automatically stored on the English lecturer channel. They could see the video of English TOEFL on the YouTube channel "English with Miss Tira" which can be accessed on https://www.youtube.com/c/EnglishWithMissTira. While, 40 students, or $25.8 \%$ agreed that by using YouTube Live Streaming, students could interact with questions and answer lecturers via Live Chat available during streaming. Simonson et al., (2018:44) state that YouTube is a natural open educational resource for presenting content knowledge. Through Live Streaming, students can take advantage of the video commentary feature for class discussions. Of course, the discussion is online and will not be hampered by time problems. When a lecturer or student uploads a video on the class channel that has been created, each class member can comment and provide feedback, ask, or answer questions.

Related to the level of understanding of the TOEFL material delivered by the lecturer using both Zoom Meeting and YouTube Live Streaming, three sections of TOEFL material have been explained and discussed by using those platforms. The listening section showed that most students (129 students or $83.2 \%$ ) very understand TOEFL material especially the listening section. In the reading section, most students (139 students or $89.7 \%$ ) understood the TOEFL material especially the reading section. In the Structure and Written Expression section, most students (126 students or $81.3 \%$ ) also understood the TOEFL material especially Structure and Written Expression section.

Several problems also can affect students during the learning English TOEFL by using both Zoom Meeting and YouTube Live Streaming. Most students (129 students or 83.2 \%) had problems with internet connection in using Zoom Meeting and YouTube Live Streaming in learning English TOEFL. Online learning is very dependent on the internet, if the network is slow or has difficult signals, the learning process will be left behind. A device connected to the internet with a minimum speed of $3 \mathrm{G}$. Zoom Meeting will adjust the image quality to your internet bandwidth, but you must have a minimum bandwidth of $600 \mathrm{kbps}$ to $1.2 \mathrm{Mbps}$. Devices that are connected to the internet will make it easier for lecturers who want face-toface lectures via video call applications such as Zoom and Live YouTube that require a smooth internet network. While the other problems are: 1) internet quota. Online learning also requires a large data package or internet quote. 2) technical problems of the device (such as a low battery, dead device suddenly, audio quality, video on the device and others), 3) types of device used, and 4) surrounding conditions (such as light conditions, ambient sounds, or other disturbances). 
Related to several choices of the students in using synchronous learning (e-learning platform) in the next learning system, most students (125 students or $80.6 \%$ ) agreed that in the next learning system on English TOEFL prediction 2 implement face-to-face teaching and learning process. 59 students or $38.1 \%$ choose "Zoom Meeting". 50 students or $32.3 \%$ chose "YouTube Live Streaming". 23 students or $14.8 \%$ stated "institutions' e-learning platform". While only 8 students or $5.2 \%$ stated "other e-learning platform".

\section{CONCLUSION}

The word synchronous means "same time". This is a method of learning where computer learning is carried out or carried out at the same time as teaching by the teacher and learning by the students. This facilitates direct contact, either via the internet or via the intranet, between lecturers/teachers and students/learners. Synchronous learning demands that teachers and students concurrently enter the e-learning system. In short, this type of elearning is almost the same as direct learning in the classroom. The use of synchronous learning became very popular during the COVID-19 pandemic, along with all classical activities, gathering large numbers of people in one place became impossible. Therefore, the Physical Distancing icon is one of the "medicine" to break the chain of the spread of the COVID-19 pandemic.

The potential to teach digitally in the digital world is an important ability that any teacher and educator should possess. Classes have moved to interactive networks and synchronous learning or other virtual platforms because of the current pandemic, and the importance of online education has risen significantly. It is important to remember that the various platforms, ranging from simple ones like WhatsApp, Telegram, Social media (Facebook, Twitter, Instagram) to some rather complex LMS like Moodle, Edmodo, Schoology or any video conferencing such as YouTube, Zoom, Webex or Google Meet are just media or tools to facilitate teaching and learning process. These are not a determinant of success in online learning. Meanwhile, the quality of learning outcomes is still determined by how the teacher delivers the learning material. There is no direct relationship between the quality of learning outcomes and whether the platform is effective or not.

\section{REFERENCES}

Atti, B. (2019). The Digital Ninja Toolbox: 101+ Digital Tools \& Resources for Every Digitally Mobile African. Bestie Atti.

Caporali, E., \& Trajkovik, V. (2012). Video Conference as a Tool for Higher Education: The TEMPUS ViCES Experience. Firenze University Press.

Chaska, N. L. (2000). The Nursing Profession: Tomorrow and Beyond. SAGE Publications.

Daniel, C. (2021). Advancing Online Course Design and Pedagogy for the 21st Century Learning Environment. IGI Global.

Dewi, Andyani, \& Piscayanti. (2019). Students' Perception on the Design of Asynchronous Online Discussion Using Schoology in English Language Education of Ganesha University. International Journal of Language and Literature, 3(1), 1-9. https://doi.org/10.23887/ijll.v3i1.20597 
Emtinan, A. (2019). Handbook of Research on Fostering Student Engagement With Instructional Technology in Higher Education. IGI Global.

Fitria, T. N. (2020). Teaching English through Online Learning System during COVID-19 Pandemic. Pedagogy: Journal of English Language Teaching, 8(2), 138-148. https://doi.org/10.32332/pedagogy.v8i2.2266

Fitria, T. N. (2021). Implementation of Institution's E-Learning Platform in Teaching Online at ITB AAS Indonesia. EDUTEC: Journal of Education and Technology, 4(3), 493503. https://doi.org/10.29062/edu.v4i3.157

Fulsawange, P. S., Mendhe, D. H., \& Sadaphal, D. S. (2020). Impact of COVID-19 on Education, Agriculture, Science, and Technology. Onlinegatha.

Ghazal, S., Samsudin, Z., \& Aldowah, H. (2015). Students' Perception of Synchronous Courses using Skype-based Video Conferencing. Indian Journal of Science and Technology, 8(30). https://doi.org/10.17485/ijst/2015/v8i1/84021

Gratton, C., \& Jones, I. (2004). Research Methods for Sports Studies. Psychology Press.

Gratton, C., \& Jones, I. (2010). Research Methods for Sports Studies. Taylor \& Francis.

Gulsun, E. (2015). Identification, Evaluation, and Perceptions of Distance Education Experts. IGI Global.

Guzacheva, N. (2020). Zoom Technology as an Effective Tool for Distance Learning in Teaching English to Medical Students. Bulletin of Science and Practice, 6, 457-460. https://doi.org/10.33619/2414-2948/54/61

Hofmann, J. (2003). The Synchronous Trainer's Survival Guide: Facilitating Successful Live and Online Courses, Meetings, and Events. John Wiley \& Sons.

Holsapple, C. (2003). Handbook on Knowledge Management 2: Knowledge Directions. Springer Science \& Business Media.

Hong Ng, C. (2020). Communicative Language Teaching (CLT) through Synchronous Online Teaching in English Language Preservice Teacher Education. International Journal of TESOL Studies. https://doi.org/10.46451/ijts.2020.09.06

Horvat, E. (2015). The Beginner's Guide to Doing Qualitative Research: How to Get into the Field, Collect Data, and Write Up Your Project. Teachers College Press.

Jiyoon, Y., \& Peggy, S. (2019). Educational Technology and Resources for Synchronous Learning in Higher Education. IGI Global.

Krakower, B., \& Blumengarten, J. (2020). Connecting Your Students with the Virtual World: Tools and Projects to Make Collaboration Come Alive. Routledge.

Lotfi, A. R., \& Pozveh, S. M. H. H. (2019). The Effect of Synchronous and Asynchronous Language Learning: A Study of Iranian EFL Intermediate Students' Vocabulary Learning. Theory and Practice in Language Studies, 9(12), 1585. https://doi.org/10.17507/tpls.0912.16 
Manning, S., \& Johnson, K. E. (2020). Online Learning For Dummies. John Wiley \& Sons.

Mary, S.-C., Cynthia. (2019). Exploring Online Learning Through Synchronous and Asynchronous Instructional Methods. IGI Global.

Miles, M. B., \& Huberman, A. M. (1994). Qualitative Data Analysis: An Expanded Sourcebook. SAGE.

Perveen, A. (2016). Synchronous and Asynchronous E-Language Learning: A Case Study of Virtual University of Pakistan. Open Praxis, 8(1), 21-39. https://doi.org/10.5944/openpraxis.8.1.212

Punch, K. F. (2013). Introduction to Social Research: Quantitative and Qualitative Approaches. SAGE.

Rahayu, D. (2020). Students' E-Learning Experience through a Synchronous Zoom Web Conference System. Journal of ELT Research: The Academic Journal of Studies in English Language Teaching and Learning, 68-79. https://doi.org/10.22236/JER_Vol5Issue1pp68-79

Richard, C. (2008). Enhancing E-Learning with Media-Rich Content and Interactions. IGI Global.

Sarkar, D. R. (2020). Environmental Sustainability in the 21st Century: Emerging Issues and the Way Forward. Namya Press.

Shukri, A., Nordin, L., Salleh, F. I. M., Raidzwan, S. N. M., \& Ahmad, R. (2020). UniKL Students' Perception on Synchronous Learning Using ICT as Learning Tools to Learn English. Journal of Critical Reviews, 7(8), 793-796. http://www.jcreview.com/?mno=112831

Simonson, M., Schlosser, C., \& Flores, J. G. (2018). Distance Learning - Issue: Volume 15 \#1. IAP.

Tekerek, M. (2020). EDUCCON 2020 Empower Teaching Studies. Mehmet Tekerek.

Waghmare, K. M., \& Waghmare, M. K. (2020). U.G.C. Care Listed Research Article Trends Of Pure Science And Applied Disciplines In Higher Education System In India And Abroad During COVID-19 Lockdown Period. Blue Diamond Publishing. 